\title{
PENGARUH SUHU DAN WAKTU STERILISASI TERHADAP NILAI F DAN KONDISI FISIK KALENG KEMASAN PADA PENGALENGAN GUDEG
}

\author{
The Effect of Temperature and Time of Sterilization on the F Value and The Physical Cans \\ Conditions in Canned Gudeg \\ Asep Nurhikmat', Bandul Suratmo', Nursigit Bintoro', Suharwadji2 \\ ${ }^{1} J u r u s a n$ Teknik Pertanian, Fakultas Teknologi Pertanian, Universitas Gadjah Mada, \\ Jl. Flora No. 1, Bulaksumur, Yogyakarta 55281 \\ ${ }^{2}$ Pusat Penelitian Fisika, Lembaga Ilmu Pengetahuan Indonesia, Gedung 60, Kompleks LIPI, \\ Jl. Sangkuriang, Bandung 40135 \\ Email: asep.nurhikmat@yahoo.com
}

\begin{abstract}
ABSTRAK
Pengalengan makanan adalah suatu cara pengawetan bahan pangan yang dikemas kemudian disterilkan. Sterilisasi dilakukan pada suhu dan waktu tertentu. Penelitian tentang pengaruh suhu dan waktu sterilisasi terhadap nilai F dan kondisi fisik kemasan pada pengalengan gudeg telah dilakukan. Tujuan penelitian adalah untuk mengetahui pengaruh sterilisasi terhadap nilai F dan kondisi fisik kemasan. Sterilisasi dilakukan pada suhu $111 ; 121$ dan $131^{\circ} \mathrm{C}$ selama $10 ; 20$ dan 30 menit. Selama proses sterilisasi, riwayat kenaikan suhu bahan di rekam dengan menggunakan data logger. Data yang dihasilkan kemudian di analisis nilai sterilitasnya. Pengamatan kondisi fisik kaleng dilakukan setelah sterilisasi secara visual menggunakan scanning electron microscope (SEM). Penelitian ini menghasilkan suhu sterilisasi sangat berpengaruh terhadap kenaikan nilai $\mathrm{F}$ dari pada waktu sterilisasi dengan nilai $\mathrm{F}$ terendah yaitu 0,123 menit terjadi pada perlakuan $111^{\circ} \mathrm{C}$ selama 10 menit dan nilai $\mathrm{F}$ tertinggi yaitu 112,504 menit terjadi pada perlakuan $131^{\circ} \mathrm{C}$ selama 30 menit. Kondisi fisik kemasan mengalami kerusakan pada suhu $131^{\circ} \mathrm{C}$ dengan persentase kerusakan terkecil yaitu $42 \%$ terjadi waktu 10 menit dan terbesar yaitu $75 \%$ pada waktu 30 menit. Perlakuan yang paling optimal adalah pada sterilisasi $121^{\circ} \mathrm{C}$ selama 20 menit dengan nilai $\mathrm{F}$ sebesar 4,425 menit dimana seluruh kaleng yang dihasilkan memiliki kenampakan yang normal. Analisis visualisasi dan karakterisasi dengan menggunakan SEM menghasilkan kerusakan lacquer terjadi pada suhu sterilisasi $131^{\circ} \mathrm{C}$ selama 30 menit dan aluminium menurun sebesar $13,85 \%$.
\end{abstract}

Kata kunci: Gudeg kaleng, pengalengan, kondisi fisik kaleng, sterilisasi.

\begin{abstract}
Canning food is a way of preserving foodstuffs was then sterilized. Sterilization was done at a certain time and temperature. Research on the effects of temperature and time sterilization on the $\mathrm{F}$ value and the physical cans conditions in canned gudeg had done. The research objective was to determine the effect of sterilization on the $\mathrm{F}$ value and the physical cans conditions. Sterilization was carried out at $111 ; 121$ and $131^{\circ} \mathrm{C}$ for $10 ; 20$ and 30 minutes. During the sterilization process, a history of substance temperature rise recorded by using a data logger. The data generated in the analysis of the value of sterility. Observations physical condition after sterilization canned done visually using a scanning electron microscope (SEM). This research resulted in the sterilization temperature influence on the increase in $\mathrm{F}$ value from the time of sterilization with the lowest $\mathrm{F}$ value is 0.123 minutes occurred in the treatment of $111^{\circ} \mathrm{C}$ for 10 minutes and the highest $\mathrm{F}$ value is 112.504 minutes occurred at $131^{\circ} \mathrm{C}$ for 30 minutes treatment. The physical condition of the packaging is damaged at a temperature of $131^{\circ} \mathrm{C}$ with the smallest percentage of damage that is $42 \%$ occurred within 10 minutes and the largest is $75 \%$ at 30 minutes. The most optimal treatment is the sterilization of $121^{\circ} \mathrm{C}$ for 20 minutes with $\mathrm{F}$ value of 4.425 minutes where all cans produced has a normal appearance. Analysis visualization and characterization using SEM produce lacquer damage occurs at a temperature of $131^{\circ} \mathrm{C}$ for 30 minutes sterilization and aluminum decreased by $13.85 \%$.
\end{abstract}

Keywords: Canned gudeg, canning, the physical cans condition, sterilization. 


\section{PENDAHULUAN}

Gudeg adalah makanan tradisional khas Yogyakarta berbahan baku nangka muda yang disajikan bersama-sama dengan daging ayam, telur, krecek kulit dan areh. Terdapat dua jenis gudeg yaitu gudeg basah dan gudeg kering. Pemasakan gudeg basah dilakukan satu kali sampai airnya habis sedangkan pemasakan gudeg kering dilakukan dua kali atau lebih. Kemasan gudeg biasanya menggunakan besek bambu atau kendil tanah liat sehingga masa simpannya singkat antara 1 sampai 2 hari. Untuk meningkatkan masa simpan perlu dilakukan pengembangan produk dengan menggunakan teknologi yang lebih modern salah satunya adalah teknologi pengalengan (Nurhikmat dkk., 2011).

Pengalengan makanan adalah suatu cara pengawetan bahan pangan yang dikemas secara hermetis kemudian disterilkan. Pengemasan secara hermetis mengandung arti penutupan dilakukan dengan sangat rapat, sehingga tidak dapat ditembus oleh udara, air dan mikroba. Metode ini dapat diterapkan pada hampir semua jenis makanan seperti sayuran, buah, daging, ikan, unggas, susu, telur, dan berbagai jenis minuman (Larousse dan Brown, 1997). Teknologi pengalengan bukan merupakan teknologi baru tetapi masih banyak hal yang belum dikuasai terutama tahapan proses untuk bahan baku yang berbeda (Awuah dkk., 2007).

Salah satu operasi yang paling penting dalam proses pengalengan makanan adalah sterilisasi. Proses ini bertujuan untuk menghancurkan mikroba pembusuk dan patogen, membuat produk menjadi matang dengan tekstur dan cita rasa sesuai dengan yang diinginkan. (Chinesta dkk, 2002; Kiziltas, 2010). Sterilisasi harus dilakukan pada kisaran suhu sterilisasi yaitu $121^{\circ} \mathrm{C}$ pada waktu tertentu, dimana panas yang diberikan cukup untuk menghancurkan bakteri patogen tetapi tidak cukup untuk menurunkan kualitas gizi dan organoleptik makanan yang dikalengkan. Menurut Kiziltas dkk (2010) bahwa jumlah panas yang diperlukan untuk sterilisasi yang memadai tergantung pada beberapa faktor yaitu: 1) Ukuran kaleng dan keadaan isinya, kaleng dengan ukuran besar memerlukan waktu lebih lama dari pada kaleng berukuran kecil; 2) Jenis bahan, penetrasi panas pada bahan cair akan lebih cepat dari pada bahan padat; 3) $\mathrm{pH}$ bahan pangan, waktu sterilisasi bahan pangan berasam rendah dapat diperpendek dengan pemanasan pada suhu lebih tinggi; 4) Suhu awal bahan, suhu awal yang cukup $\left(50\right.$ sampai $\left.60^{\circ} \mathrm{C}\right)$ dapat memperpendek waktu sterilisasi; 5) Sumber panas, uap air sebagai medium pemanasan harus merupakan uap air murni, sehingga proses perpindahan panas berjalan dengan cepat.

Istilah sterilisasi mengandung arti suatu perlakuan penghancuran semua mikroba beserta sporanya. Derajat sterilitas yang cukup dapat diperoleh bila titik terdingin dalam kaleng cukup menerima panas untuk menghancurkan mikroba. Derajat sterilitas biasanya direpresentasikan sebagai nilai $\mathrm{F}$ yaitu waktu dalam menit pada suhu $121^{\circ} \mathrm{C}$ yang diperlukan untuk menghancurkan mikroba. Nilai $\mathrm{F}$ ini tergantung pada suhu proses dan nilai $\mathrm{Z}$ (perubahan suhu) dimana mikroba hancur sebesar $1 \log$ atau $10^{\mathrm{n}}$ (Stumbo, 1973; Teixeira, 1992; Stoforos, 1995; Goncalves, 2005; Tucker dkk, 2007). Menurut Stumbo (1973); Lewis (1987); Teixeira (1992); Larousse dan Brown (1997); Cuesta-Benito dan Lamua (2002); Goncalves dkk (2005) nilai F dapat dihitung dengan persamaan:

$$
F=\int_{0}^{t} \log ^{-1}\left[\frac{T-T_{\text {ref }}}{Z}\right] d t
$$

Nilai $\mathrm{Z}$ berhubungan erat dengan resistensi atau ketahanan mikroba dan sporanya terhadap panas seperti terlihat pada Gambar 1. Resistensi panas mikroba dinyatakan sebagai waktu kematian thermal atau thermal death time (TDT) yaitu waktu yang dibutuhkan untuk membunuh mikroba pada jumlah tertentu pada kondisi fisik tertentu. TDT pada suhu $121^{\circ} \mathrm{C}$ digunakan sebagai referensi sterilitas dan dinyatakan sebagai Fo (Stumbo, 1973; Lewis, 1987; Teixeira, 1992).

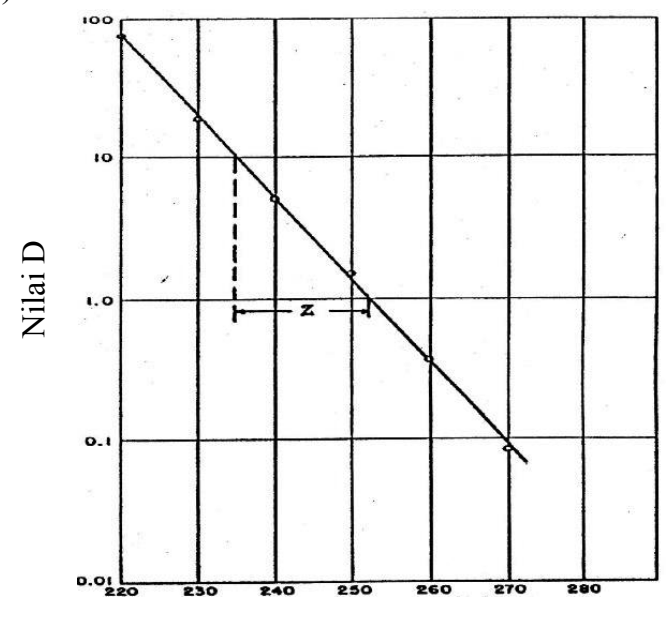

Gambar 1. Grafik nilai Z (Teixeira, 1992)

Proses sterilisasi di rancang untuk mematikan semua mikroba termofil pembentuk spora tetapi akibatnya bahan pangan terlalu matang atau over cooking dan menyebabkan turunnya nilai gizi. C. botulinum baik bentuk vegetatif atau sporanya memiliki resisten terhadap panas. Bentuk vegetatif C. botulinum lebih mudah dimatikan dengan panas lembab pada suhu di bawah $100^{\circ} \mathrm{C}$, tetapi bentuk sporanya relatif lebih tahan (Tucker dkk., 2007). Mikroba ini memiliki resistensi terhadap panas pada suhu $121^{\circ} \mathrm{C}$ selama 2,8 menit (Stumbo, 1973). Sterilisasi standar harus dilakukan pada suhu $121^{\circ} \mathrm{C}$ selama 3 menit dan biasa disebut sebagai $F_{0} 3$ atau botulinum cook (DoH, 1994; FDA, 2005). 
Selain berpengaruh terhadap gizi dan organoleptik, panas yang diberikan selama sterilisasi juga dapat merusak lapisan enamel kaleng atau lacquer. Lacquer adalah suatu lapisan yang membatasi kontak makanan dengan kaleng. Dari semua jenis lacquer, jenis aluminize merupakan pembatas yang paling baik. Selain lacquer jenis aluminium ada juga lacquer berbasis bahan organik tetapi sejak pertama kontak dengan makanan biasanya bereaksi secara elektrokimia sehingga lapisan menjadi berlubang (Barilli dkk., 2003). Beberapa faktor yang berpengaruh terhadap laju kerusakan lapisan diantaranya adalah waktu dan suhu proses serta tingkat kevakuman kaleng (Page dkk., 2003; Rubio, 2005).

Beberapa penelitian yang telah dilakukan antara lain pengaruh struktur dan campuran berbasis resin pada kondisi fisik lacquer (Karyakina dkk., 1968), pengaruh tekanan tinggi terhadap kondisi fisik lacquer berbasis EVOH pada kemasan makanan (Rubio dkk., 2005), pengaruh lacquer berbasis epoxy terhadap kadaluarsa kaleng (Bernardo dkk., 2005) dan adhesi beberapa tipe lacquer yang digunakan pada kemasan makanan (Barilli dkk., 2003).

Tujuan umum penelitian adalah mempelajari pengaruh suhu dan waktu sterilisasi terhadap nilai $\mathrm{F}$ dan kondisi fisik kemasan pada pengalengan gudeg. Tujuan khusus penelitian adalah: 1) optimasi suhu dan waktu berdasarkan nilai $\mathrm{F}$ dan kondisi fisik kemasan yang baik, 2) mengetahui pengaruh sterilisasi terhadap kerusakan lacquer kaleng, dan 3) mengetahui perubahan karakterisasi lacquer akibat sterilisasi.

\section{METODE PENELITIAN}

Bahan yang dipakai dalam penelitian adalah gudeg Bu Tjitro 1925 terdiri dari 40,260\% nangka muda; 21,543\% telur bebek; 7,791\% daging ayam; 8,060\% kacang tolo dan $15,346 \%$ krecek. Alat yang digunakan antara lain: kaleng jenis two pieces can ukuran diameter $74,92 \mathrm{~mm}$ dan tinggi 58,22 mm (300x205). Lacquer bagian dalam kaleng dari jenis aluminize lacquer; Double seamer merk Varin, kapasitas 48 can per menit; Autoclave merk TOMMY SS-325 dengan spesifikasi voltage $220 \mathrm{~V} \mathrm{50/60} \mathrm{Hz,10} \mathrm{A,} \mathrm{kapasitas} 0,053$ $\mathrm{m}^{3}$; Data logger merk ELLAB CTF9004 dengan spesifikasi suhu maksimum sampai $350^{\circ} \mathrm{C}$ dengan akurasi $0,1^{\circ} \mathrm{C}$; serta scanning electron microscope (SEM) merk JEOL tipe JED 2300.

Penelitian dilakukan dengan memasukkan bahanbahan gudeg ke dalam kaleng kemudian ditutup. Sterilisasi dilakukan pada suhu $111 ; 121$ dan $131^{\circ} \mathrm{C}$ selama $10 ; 20$ dan 30 menit. Pengamatan dilakukan selama proses dan setelah proses sterilisasi. Selama sterilisasi dilakukan uji heat penetration test hasilnya berupa riwayat suhu sterilisasi. Pengamatan setelah proses sterilisasi dilakukan terhadap kondisi fisik kaleng bagian luar secara visual dan bagian lacquer menggunakan scanning electron microscope (SEM). Skema uji heat penetration test disajikan pada Gambar 2 sementara diagram alir penelitian disajikan pada Gambar 3.

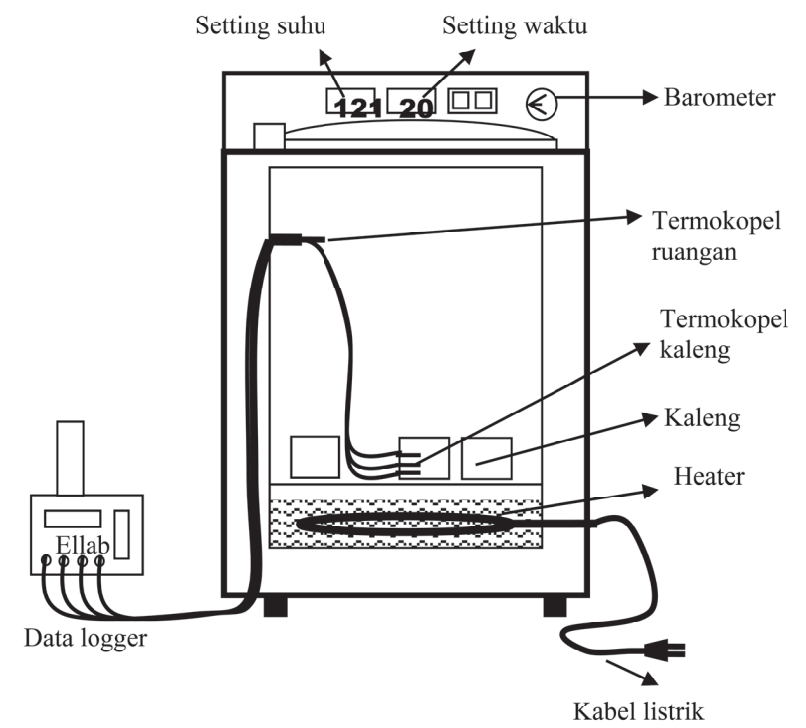

Gambar 2. Skema posisi kaleng pada retort

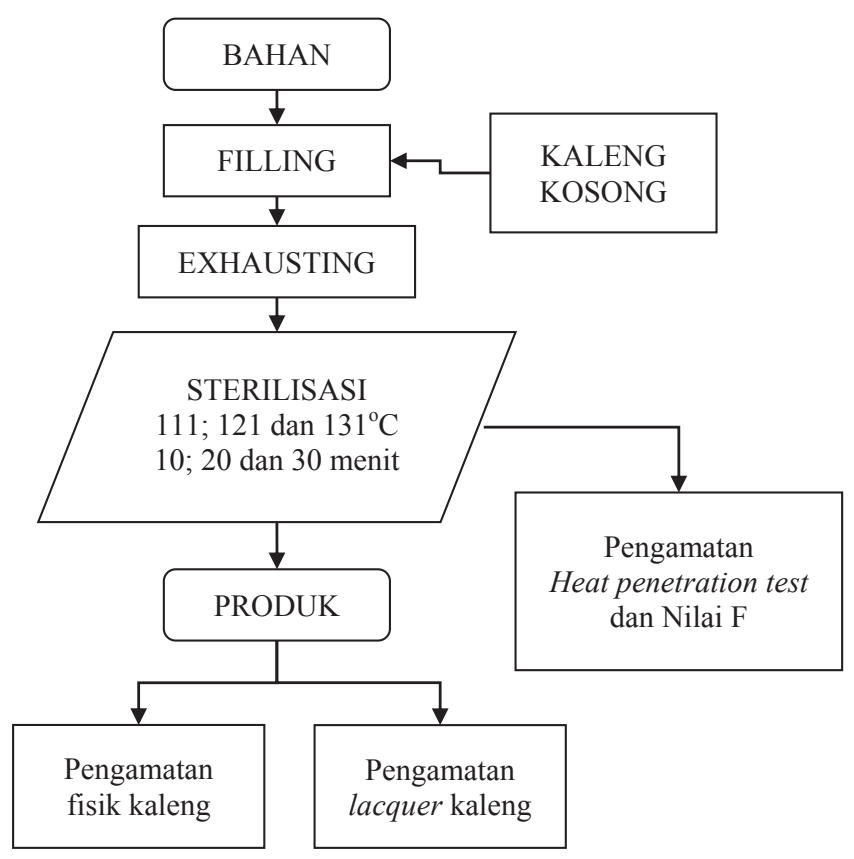

Gambar 3. Diagram alir penelitian

\section{HASIL DAN PEMBAHASAN}

Bila suatu makanan di kemas dalam kaleng dan diletakkan dalam retort, suhu produk tidak segera mencapai suhu proses, tetapi panas akan merambat secara perlahanlahan. Kecepatan penetrasi panas dari retort ke dalam produk 
dapat diketahui dengan heat penetration test. Pengukurannya dilakukan dengan meletakkan ujung termokopel pada bagian terdingin (Teixeira, 1992; Stoforos, 1995).

Hasil pengamatan suhu pada perlakuan suhu $111 ; 121$ dan $131^{\circ} \mathrm{C}$ selama $10 ; 20$ dan 30 menit disajikan pada Gambar 4 sampai Gambar 6.

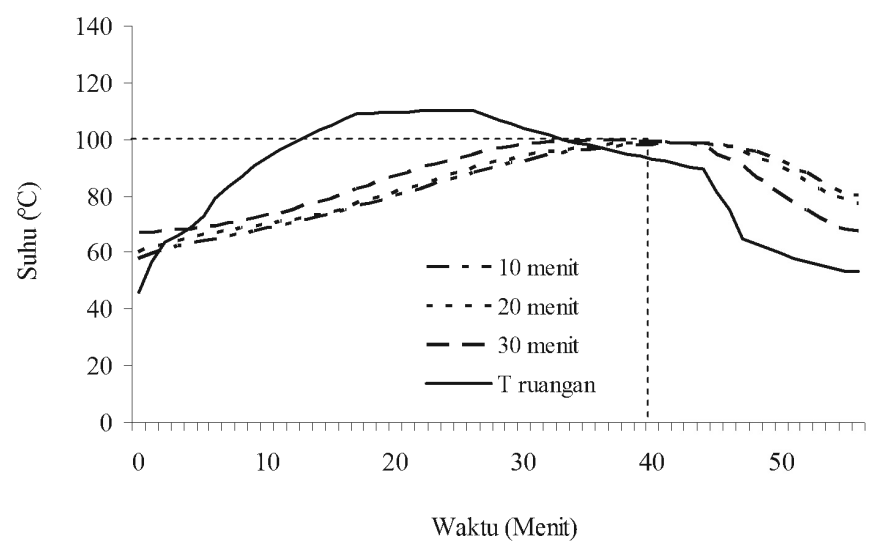

Gambar 4. Riwayat suhu pada pemanasan suhu $111^{\circ} \mathrm{C}$

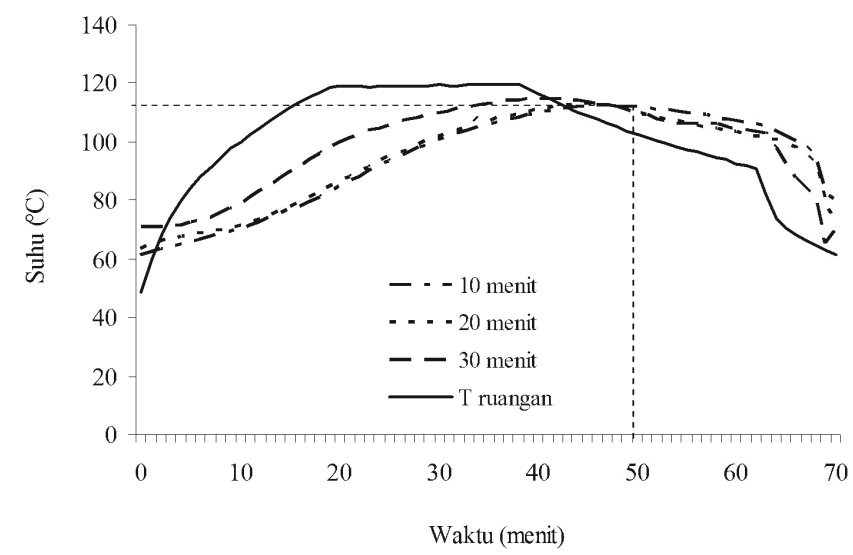

Gambar 5. Riwayat suhu pada pemanasan suhu $121^{\circ} \mathrm{C}$

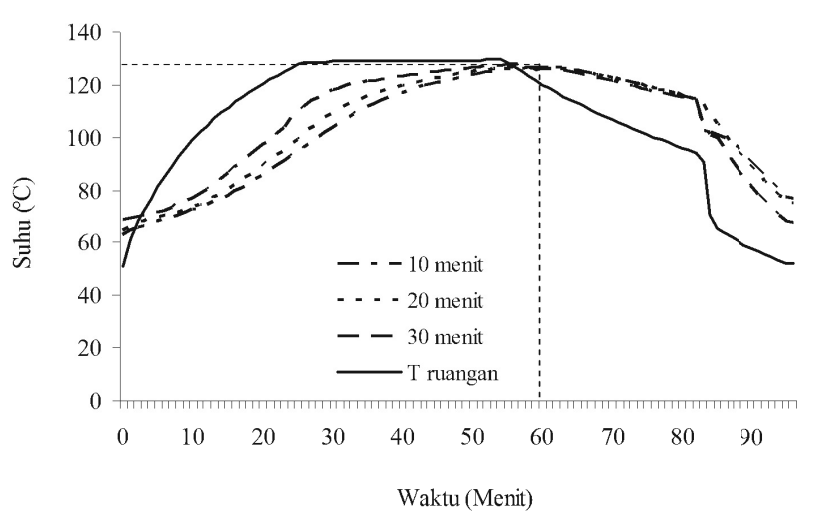

Gambar 6. Riwayat suhu pada pemanasan suhu $131 \mathrm{oC}$
Gambar 4 sampai Gambar 6 memperlihatkan riwayat suhu pada berbagai variasi perlakuan dimana suhu tertinggi dan waktu yang dicapai pada suhu bahan berbeda. Pada perlakuan $111^{\circ} \mathrm{C}$ suhu tertinggi adalah $100^{\circ} \mathrm{C}$ tercapai pada menit ke 40 , pada perlakuan $121^{\circ} \mathrm{C}$ suhu tertinggi adalah $112^{\circ} \mathrm{C}$ tercapai pada menit ke 50 dan pada perlakuan $131^{\circ} \mathrm{C}$ suhu tertinggi adalah $128^{\circ} \mathrm{C}$ tercapai pada menit ke 60 . Hal ini disebabkan karena semakin tinggi suhu maka waktu sterilisasi yang dibutuhkan untuk mencapai suhu yang dinginkan semakin lama (Teixeira, 1992; Stoforos, 1995; Goncalves, 2005; Tucker dkk., 2007).

Proses sterilisasi erat kaitannya dengan derajat sterilitas atau nilai $\mathrm{F}$ yang diperoleh pada titik terdingin dalam kaleng. Dengan mengetahui data kenaikan suhu pada bahan maka nilai $\mathrm{F}$ pada masing-masing perlakuan dapat dianalisis dengan menggunakan persamaan 1 . Hasil analisis nilai $F$ pada berbagai perlakuan disajikan pada Gambar 7 sampai Gambar 9.

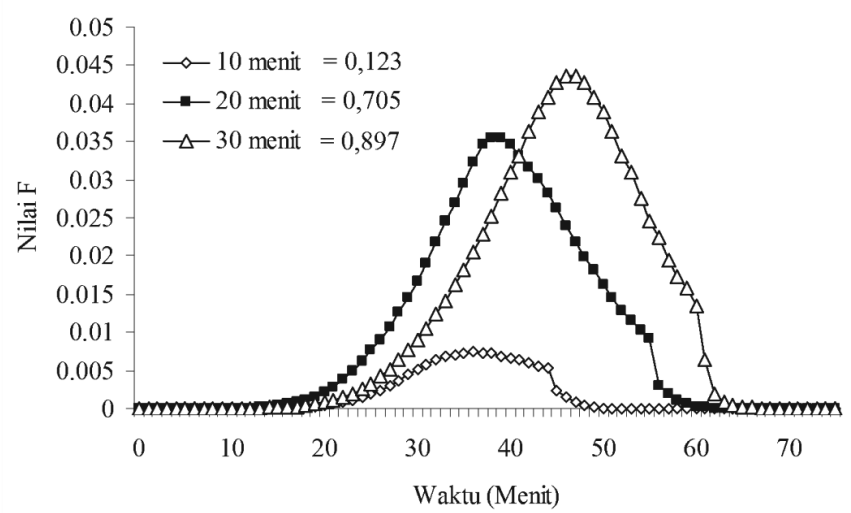

Gambar 7. Nilai F pada pemanasan suhu $111^{\circ} \mathrm{C}$

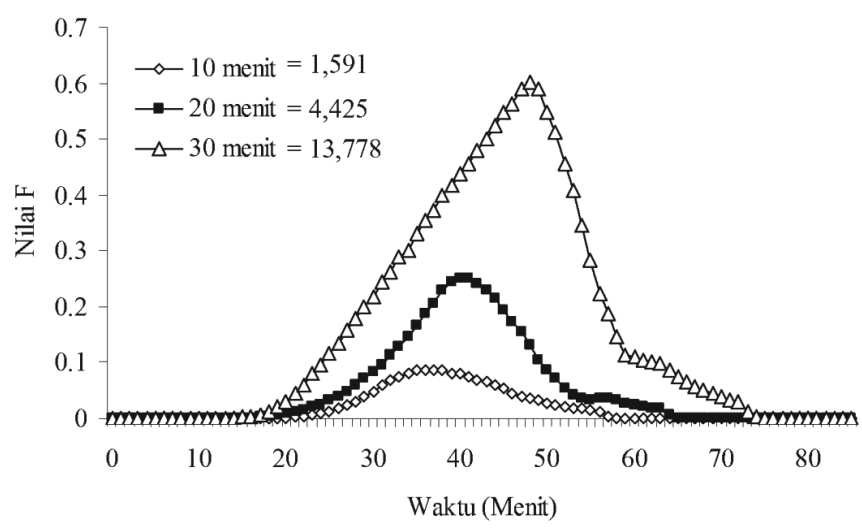

Gambar 8. Nilai F pada pemanasan suhu $121^{\circ} \mathrm{C}$ 


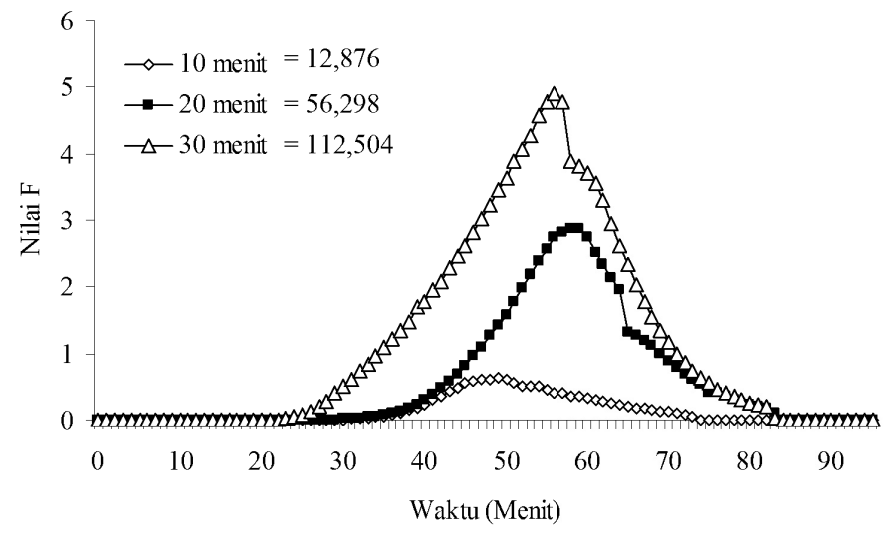

Gambar 9. Nilai F pada pemanasan suhu $131^{\circ} \mathrm{C}$

Pada Gambar 7 sampai Gambar 9 terlihat semakin tinggi suhu dan semakin lama sterilisasi nilai $\mathrm{F}$ semakin besar. Nilai $\mathrm{F}$ terkecil diperoleh pada perlakuan $111^{\circ} \mathrm{C}$ selama 10 menit sebesar 0,123 menit dan nilai $\mathrm{F}$ terbesar diperoleh pada perlakuan $131^{\circ} \mathrm{C}$ selama 30 menit sebesar 112,504 menit. Beberapa penelitian yang terlah dilakukan untuk mengestimasi makanan asam dalam kaleng dengan $T$ referensi $121,1^{\circ} \mathrm{C}$ untuk membunuh Clostridium botulinum adalah 3 menit (Fryer dan Robbins, 2005). Adapun untuk makanan dengan pH lebih besar dari 4,5 adalah 4,2 (Holdsworth, 1985). Berdasarkan FDA (2005) sterilisasi standar harus dilakukan pada suhu $121^{\circ} \mathrm{C}$ dengan nilai penghancuran spora Clostridium botulinum sebesar 3 menit hal ini disebut sebagai $F_{0} 3$ atau botulinum cook. Maka perlakuan terbaik diperoleh pada $121^{\circ} \mathrm{C}$ selama 20 menit sebesar 4,425 menit.

Uji korelasi dilakukan untuk mengetahui hubungan antara suhu dan waktu sterilisasi dengan nilai $\mathrm{F}$, hasilnya disajikan pada Tabel 1.

Tabel 1. Hasil uji korelasi variabel perlakuan dengan nilai $\mathrm{F}$

\begin{tabular}{ccc}
\hline & Suhu & Waktu \\
\hline Nilai F & $.896(* *)$ & .422 \\
\hline
\end{tabular}

** Correlation is significant at the 0.01 level (2-tailed)

Tabel 1 memperlihatkan hubungan antara suhu sterilisasi dan nilai $\mathrm{F}$ sangat signifikan pada level 0,01 tetapi hubungan antara waktu sterilisasi dengan nilai $\mathrm{F}$ tidak signifikan, artinya kenaikan nilai $\mathrm{F}$ lebih dipengaruhi oleh kenaikan suhu dari pada kenaikan waktu. Menurut beberapa penelitian yang telah dilakukan bahwa nilai $\mathrm{F}$ tergantung pada suhu proses dan perubahan suhu dari pada waktu proses (Stumbo, 1973; Teixeira, 1992; Stoforos, 1995; Goncalves, 2005; Tucker dkk., 2007).
Untuk mengetahui pengaruh suhu dan waktu sterilisasi dilakukan analisis kenampakan kondisi fisik kemasan, hasilnya disajikan pada Gambar 10 dan Gambar 11.

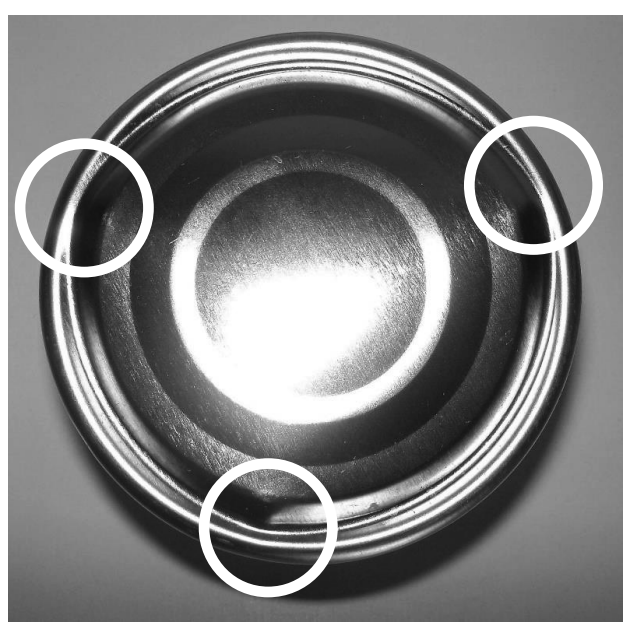

Gambar 10. Kerusakan kaleng pada 3 titik

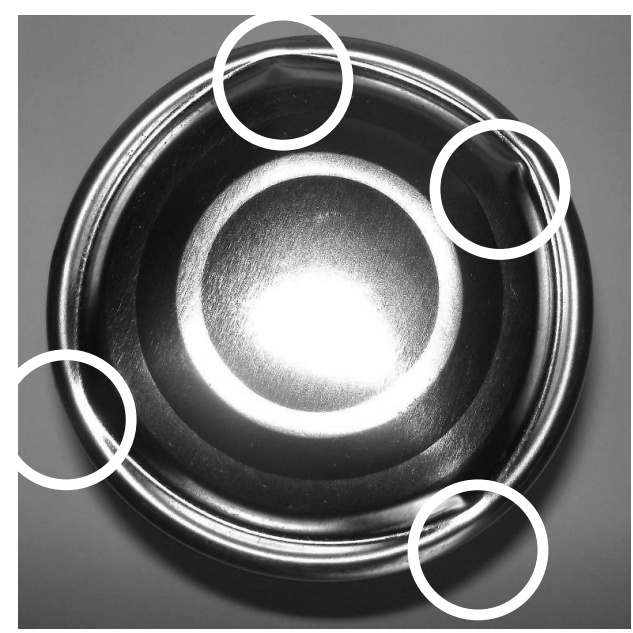

Gambar 11. Kerusakan kaleng pada 4 titik

Gambar 10 dan Gambar 11 menunjukkan kerusakan kaleng bervariasi tergantung dari kekuatan kaleng dan kerusakan ini berkondisi permanen. Kerusakan tersebut biasanya terjadi pada 1 titik, 2 titik, 3 titik atau 4 titik. Hal ini disebabkan terjadinya pemuaian bahan padat dalam kemasan kaleng akibat panas yang berlebihan sementara kekuatan kaleng menahan tekanan dalam terbatas. Pengembangan ini biasanya disebut dengan pengembungan induksi fisis (Lund, 2003; Desrosier, 2008).

Faktor-faktor yang menunjang tekanan internal kemasan antara lain pemuaian produk, koefisien muai produk, suhu awal, suhu pemanasan, tekanan uap gas dalam produk, isi dan volume headspace (Larousse dan Brown, 1997). Beberapa hal yang dapat dilakukan untuk melindungi kemasan dari induksi fisis, antara lain: 1) mengatur headspace; 2) menjaga agar 
suhu awal tinggi; 3) mengeluarkan udara sebelum ditutup (exhausting); dan 4) mengatur suhu dan waktu pemanasan. Kerusakan kemasan pada berbagai perlakuan disajikan pada Gambar 12.

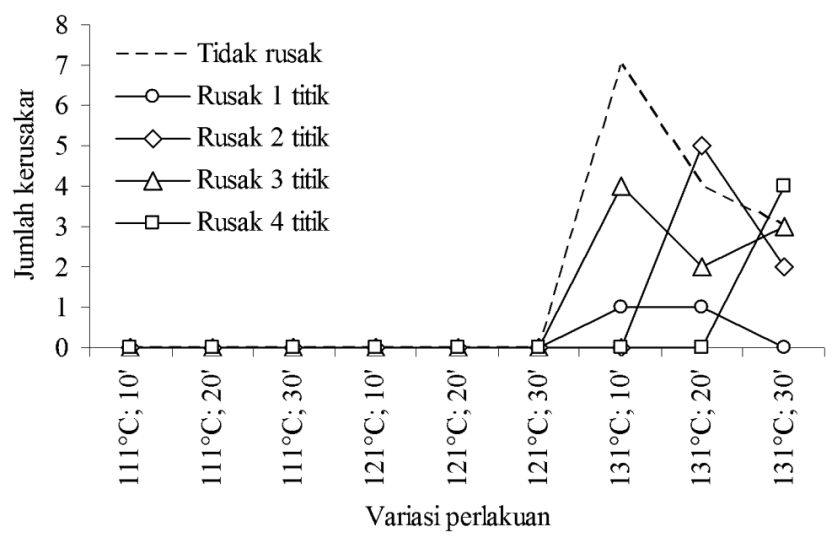

Gambar 12. Kerusakan kaleng sampel pada variasi perlakuan berbeda

Gambar 12 memperlihatkan jumlah kerusakan mulai terjadi setelah suhu dinaikan menjadi $131^{\circ} \mathrm{C}$. Jumlah kerusakan dalam persentase $(\%)$ pada berbagai perlakuan disajikan pada Tabel 2.

Tabel 2. Jumlah kerusakan kemasan (\%) pada berbagai perlakuan

\begin{tabular}{cccc}
\hline & \multicolumn{3}{c}{ Persentase kerusakan kemasan $(\%)$} \\
\cline { 2 - 4 } & $111^{\circ} \mathrm{C}$ & $121^{\circ} \mathrm{C}$ & $131^{\circ} \mathrm{C}$ \\
\hline 10 menit & 0 & 0 & 42 \\
20 menit & 0 & 0 & 67 \\
30 menit & 0 & 0 & 75 \\
\hline
\end{tabular}

Tabel 2 memperlihatkan kerusakan kemasan mulai terjadi pada suhu $131^{\circ} \mathrm{C}$ dengan persentase kerusakan terkecil (42\%) terjadi waktu 10 menit. Uji korelasi dilakukan untuk mengetahui hubungan antara suhu dan waktu sterilisasi dengan kerusakan kaleng, hasilnya disajikan pada Tabel 3.

Tabel 3. Hasil uji korelasi variabel perlakuan dengan kerusakan kaleng

\begin{tabular}{lcc}
\hline & Suhu & Waktu \\
\hline Persentase kerusakan kaleng $(\%)$ & $.833(* *)$ & .151 \\
\hline
\end{tabular}

** Correlation is significant at the 0.01 level (2-tailed)

Tabel 3 memperlihatkan hubungan suhu dengan kerusakan kaleng sangat signifikan pada level 0,01 sementara dengan waktu tidak signifikan, artinya bahwa kerusakan kaleng sangat dipengaruhi oleh suhu sterilisasi tetapi tidak dipengaruhi oleh waktu. Selain berpengaruh terhadap nilai F dan kondisi fisik kemasan, panas yang diberikan selama sterilisasi juga dapat merusak lapisan lacquer. Lacquer adalah lapisan pelindung yang membatasi kontak makanan dengan kaleng. Semua jenis lacquer aluminium merupakan pembatas yang paling baik antara makanan dan kaleng (Page dkk., 2003). Analisis pada lacquer dilakukan dengan scanning electron microscope (SEM) dengan pembesaran 500 kali. Hasil analisis SEM untuk visualisasi disajikan pada Gambar 13 sampai Gambar 15.

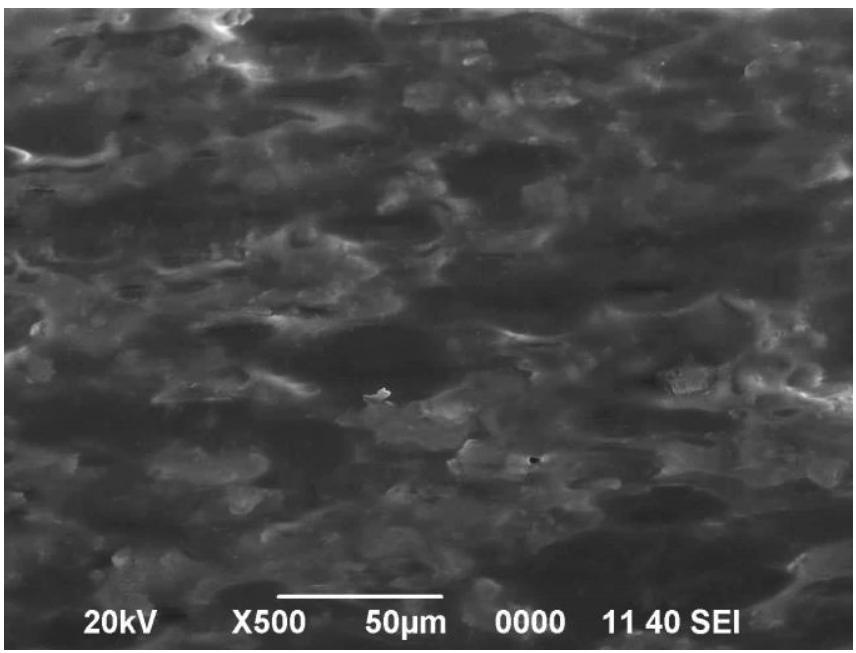

Gambar 13. Hasil SEM lacquer kaleng pada perlakuan $111^{\circ} \mathrm{C}$

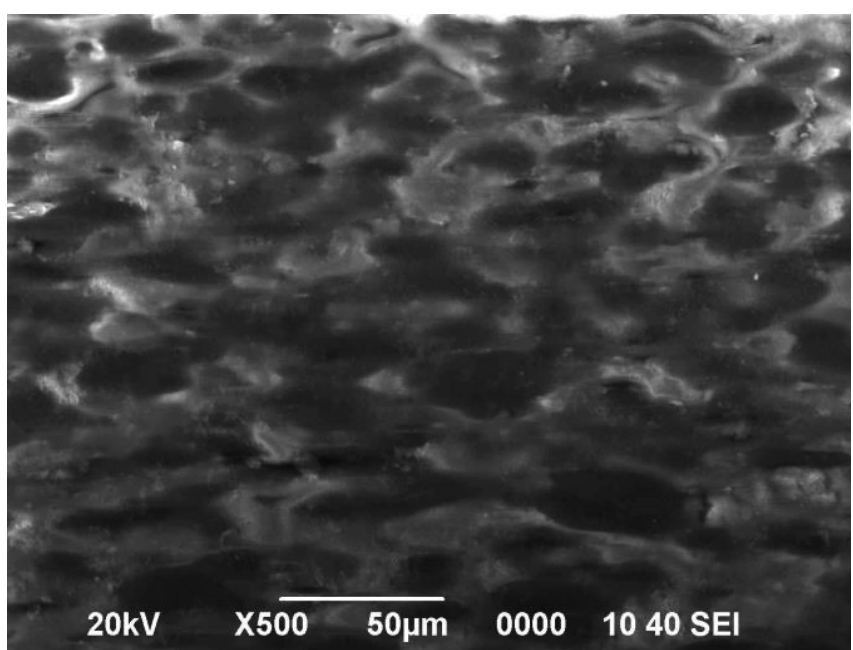

Gambar 14. Hasil SEM lacquer kaleng pada perlakuan $121^{\circ} \mathrm{C}$

Gambar 13 sampai Gambar 15 memperlihatkan semakin tinggi suhu kerusakan lacquer semakin besar (ditunjukkan dengan panah). Hal ini disebabkan karena panas yang diberikan menimbulkan tekanan internal sehingga merubah struktur dan kondisi fisik lacquer (Rubio dkk, 2005). Untuk memperjelas kerusakan analisis dilanjutkan dengan analisis karakterisasi senyawa pada lacquer, hasilnya disajikan pada Gambar 16. 


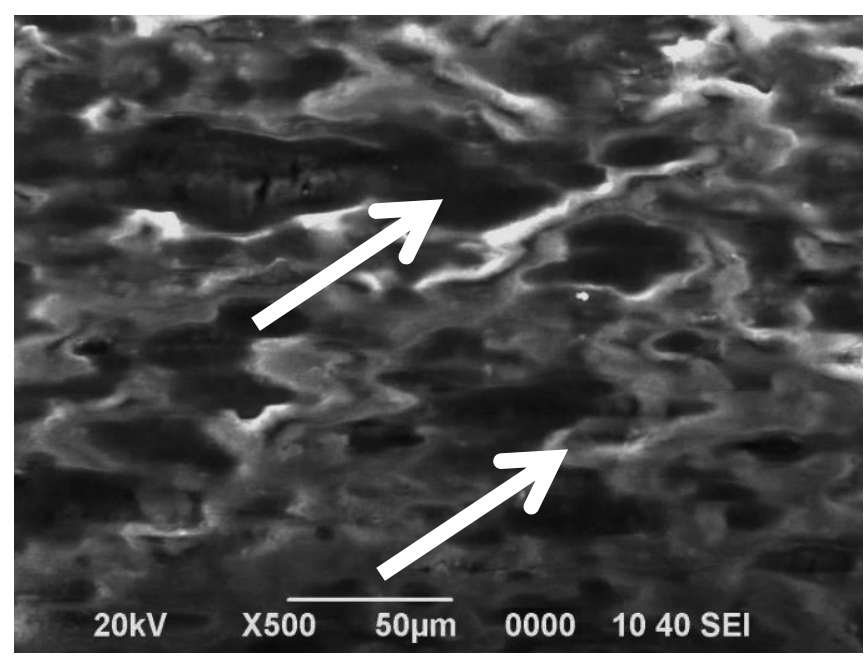

Gambar 15. Hasil SEM lacquer kaleng pada perlakuan $131^{\circ} \mathrm{C}$

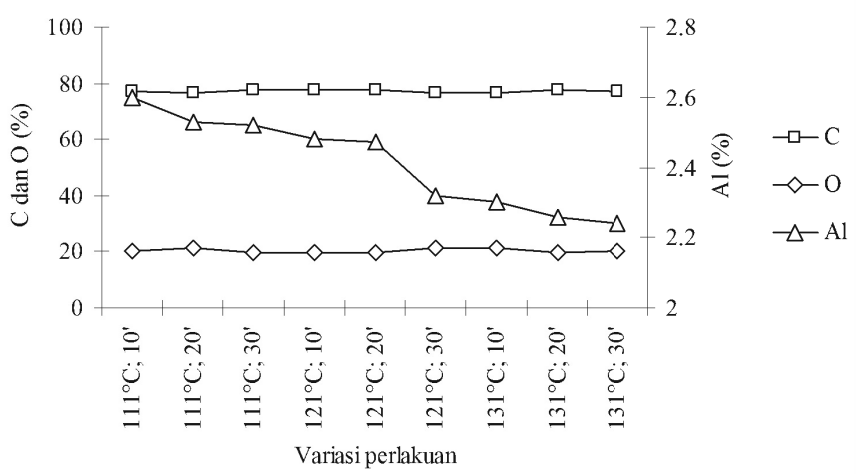

Gambar 16. Hasil karakterisasi lacquer kaleng dengan SEM

Gambar 16 memperlihatkan terjadi penurunan konsentrasi aluminium sebesar $13,85 \%$ dari konsentrasi awal. Uji korelasi dilakukan untuk mengetahui hubungan suhu dan waktu sterilisasi dengan unsur karbon, oksigen dan aluminium, hasilnya disajikan pada Tabel 4.

Tabel 4. Hasil uji korelasi variabel perlakuan dengan karakterisasi ename

\begin{tabular}{rcc}
\hline & Suhu & Waktu \\
\hline Karbon & .085 & .177 \\
Oksigen & .105 & -.107 \\
Aluminium & $-.919(* *)$ & -.324 \\
\hline
\end{tabular}

** Correlation is significant at the 0.01 level (2-tailed)

Tabel 4 memperlihatkan hubungan suhu perlakuan dan aluminium sangat signifikan pada level 0,01, artinya penurunan persentase aluminium pada lacquer sangat dipengaruhi oleh kenaikan suhu sterilisasi. Hal ini disebabkan suhu yang menyebabkan perubahan tekanan akan mempengaruhi struktur dan perubahan ikatan (adhesi) lacquer yang digunakan pada kemasan makanan (Barilli dkk., 2003).

\section{KESIMPULAN}

Suhu sterilisasi sangat berpengaruh terhadap kenaikan nilai $\mathrm{F}$ dengan nilai $\mathrm{F}$ terendah yaitu 0,123 menit terjadi pada perlakuan $111^{\circ} \mathrm{C}$ selama 10 menit dan nilai $\mathrm{F}$ tertinggi yaitu 112,504 menit terjadi pada perlakuan $131^{\circ} \mathrm{C}$ selama 30 menit. Kondisi fisik kemasan mengalami kerusakan pada suhu $131^{\circ} \mathrm{C}$ dengan persentase kerusakan terkecil yaitu $42 \%$ terjadi waktu 10 menit dan terbesar yaitu $75 \%$ pada waktu 30 menit. Perlakuan yang paling optimal adalah pada sterilisasi $121^{\circ} \mathrm{C}$ selama 20 menit dengan nilai $\mathrm{F}$ sebesar 4,425 menit dimana seluruh kaleng yang dihasilkan memiliki kenampakan yang normal. Analisis visualisasi dan karakterisasi dengan menggunakan SEM menghasilkan kerusakan lacquer terjadi pada suhu sterilisasi $131^{\circ} \mathrm{C}$ selama 30 menit dan aluminium menurun sebesar $13,85 \%$.

\section{UCAPAN TERIMA KASIH}

Terima kasih diucapkan kepada Beasiswa Kementerian Riset dan Teknologi RI atas sponsorship terhadap penulis untuk melanjutkan studinya, Gudeg Bu Tjitro 1925, Laboratorium SEM Pusat Penelitian Metalurgi LIPI dan Tim Pengalengan UPT BPPTK LIPI.

\section{DAFTAR PUSTAKA}

Awuah, G.B., Ramaswamy, H.S. dan Economides, A. (2007). Thermal processing dan quality: principles dan overview. Chemical Engineering dan Processing 46: 584-602.

Barilli, F., Fragni, R., Gelati, S. dan Montanari, A. (2003). Study on the adhesion of different laquers used in food packaging. Progress in Organic Coatings 46: 91-96.

Bernardo, P.E.M., dos Santos, J.L.C. dan Costa, N.G. (2005). Influence dan end lining Compound on the shelf life of the Steel beverage can. Progress in Organic Coatings 54: $34-42$.

Chinesta, F., Torres, R., Ramon, A., Rodrigo, M.C. dan Rodrigo, M. (2002). Homogenized Thermal Condustion Model for Particulate Foods. Journal of Food Engineering 80: 80-95.

Cuesta-Benito., F.J. dan M. Lamua. (2002). Calculation of the Minimum Mean Cooling/Heating time of GeneralGeometry Solids. Journal of Food Engineering 53: 259-271. 
Desrosier, N.W. (2008). Teknologi Pengawetan Pangan. AVI Publishing Company, Inc. Terjemahan Muchji Miljohardjo, Edisi Ketiga, Penerbit UI. Jakarta.

Departemen of Health (DoH) (1994). Guidelines for the Safe Production of Heat Preserved Foods. Her Majesty's Stationery Office. Norwich, England.

Food dan Drug Administration (FDA) (2005). Food and Drugs. Chapter 1-Food and Drug Administration Department of Health and Human Services. Subchapter B-Food for Human Consumption. Code of federal Regulations. Title 21, Volume Revised as of April 1, 2005.

Fryer, J.F. dan Robbins, P.T. (2005). Heat transfer in food processing: ensuring product quality and safety. Applied Thermal Engineering 25: 2499-2510.

Goncalves, E.C., Minim, L.A., Coimbra, J.S.R. dan Minim, V.P.R. (2005). Modelling Sterilization Process of Canned Foods using Artificial Neural Networks. Chemical Engineering dan Processing 44: 1269-1276.

Holdsworth, S.D. (1985). Optimisation of thermal processing - a review. Journal of Food Engineering 4: 89-116.

Karyakina, M.I., Maiorova, N.V., Berestneva, Z.Y. dan Kargin, V.A. (1968). The Effect of Structure on the Properties. Journal Polymer Science A10(12): 26182628.

Kiziltas, S., Erdogdu, F. dan Palazoglu, T.K. (2010). Simulation of heat transfer for solid-liquid food mixture in cans and model validation under pasteurization conditions. Journal of Food Engineering 97: 449-456.

Lewis, M.J. (1987). Physical Properties of Foods and Food Processing System. Ellis Horwood. Weinheim. German.
Larousse, J. dan Brown, B.E. (1997). Food Canning Technology. Wiley VCH. New York.

Lund, D. (2003). Predicting the impact of food processing on food constituents. Journal of Food Engineering 56: 113-117.

Nurhikmat, A., Suratmo, B., Bintoro, N. dan Suharwadji (2011). pengaruh proses pengalengan terhadap kualitas gudeg Wijilan. Prosiding Seminar Nasional APTA, Jurusan Teknologi Agroindustri. Fakultas Teknologi Pertanian. Universitas Gadjah Mada. Yogyakarta.

Page, B., Edwards, M. dan May, N. (2003). Metal Cans; in Food Packaging Technology. Chapter 5. Edited by Coles, R., D. McDowell dan M.J. Kirwan. Blackwell Publishing Asia Pty Ltd., Australia.

Rubio., A.L., Lagaron, J.M., Munoz, P.H., Almenar, E., Catala, R., Gavara, R. dan. Pascall, M.A. (2005). Effect of High Pressure Treatments on The Properties of EVOH-Based Food Packaging Material. Innovative Food Science and Emerging Technology 6: 51-58.

Stoforos, N.G. (1995). Thermal process design. Food Control 6(2): 81-95.

Stumbo, C.R. (1973). Thermobacteriology in Food Processing. $2^{\text {nd }}$ edition. Academic Press. New York.

Teixeira, A. (1992). Thermal process calculation, chapter 11. Dalam: Heldman, D.R. dan Lund, D.B. (Ed). Handbook of Food Engineering. Marcel Dekker, Inc., New York.

Tucker, G.S., Brown, H.M., Fryer, P.J., Cox, P.W., Poole II, F.L., Lee, H.S. dan Adams, M.W.W. (2007). A sterilization time-temperatur integrator based on amylase from the hyperthermophilic organism Pyrococcus furius. Innovative Food Science and Emerging Technologies 8(1): 63-72. 